\title{
TEKSTIEN MAAILMA
}

LOTMAN, JURI: Merkkien maailma. Kirjoitelmia semiotiikasta. SN-kirjat, 1989.

Merkkien maailma koostuu kahdeksasta Tarton koulukunnan johtajan Juri Lotmanin artikkelista, jotka hän on julkaissut vuosina 1973-1985. Ne käsittelevät kolmea teemaa: kulttuurisemiotiikan ja tekstin käsitteen lähtokohtia, arkielämän ja elämäkerran semiotiikkaa sekä elokuvasemiotiikkaa. Tässä arviossa käsittelen ensimmäistä ja kolmatta aihetta. Todettakoon kuitenkin, että artikkeli Dekabristin arkipäivää - joka käsittelee kapinallista käyttäytymistä määrittäviä koodeja - virittää yhteyksiä yhtäältä Lotmanin ja Pierre Bourdieun, toisaalta Lotmanin ja Erwin Goffmanin välille. Se myös herättää kysymyksen, kuinka arvokasta tekstianalyysin ja taiteentutkimuksen piirissä syntynyt semiotiikka loppujen lopuksi on arkielemän merkitysten muodostumisen tutkimiselle.

\section{Kulttuurisemiotiikka ja teksti}

Ferdinand de Saussuren strukturalistisen kieliteorian yleistyminen puhekielestä muita symbolisaatiotapoja koskevaksi mm. Claude Lévi-Straussin ja Roland Barthesin teorioiden myötä on johtanut kahteen semioottiseen teorian kehityssuuntaan. Yhtäällä ovat yritykset kehitellä yleistä teoriaa merkkijärjestelmistä ja merkityksen muodostumisesta. Näitä Lotmanin metasemiotiikaksi kutsumia edustavat $\mathrm{mm}$. Umberto Econ semioottinen teoria ja A.J. Greimasin narratologia. Toisaalla ovat pyrkimykset käsittää kulttuuri semioottisesta näkökulmasta ja kehittää semioottista käsitteistöä erilaisten kulttuuri-ilmiöiden analysoimiseksi. Kun edellisessä keskeistä on koodin ja merkin teoria, jälkimmäisen ydin on tekstin teoria.

Lotman ja 1960-luvun jälkipuoliskolla muodostunut Tarton koulukunta kuuluu jälkimmäiseen suuntaukseen. Se tunnetaan ennen kaikkea kulttuurisemiotiikan ja kulttuurien semioottisen typologisoinnin ajatuksista. Tarttolaisittain kulttuuri käsitetään merkityksellistämisjärjestelmiksi, tarkemmin sanottuna toisen asteen mallintamisjärjestelmiksi, ja jokaista kulttuuriaktiviteettia tarkastellaan tekstinä, jonka yksi tai useampi em. järjestelmä tuottaa. Kulttuureja voidaan luokitella sen mukaan, millä tavoin ne hierarkisoivat toisen asteen mallintamisjärjestelmiä, miten ne rajaavat epäkulttuurin, aika- ja tilakäsitteiden mukaan sekä sen perusteella, miten ne suhtautuvat semiosikseen. Suhtautuminen semiosikseen on oleellisin kulttuuriluokittelujen perusta. Kulttuurissa voidaan arvostaa enemmän joko olemassa olevia tekstejä tai uusien tekstien tuottamista, ts. kulttuuri on teksti- tai sääntöorientoitunut. Lisäksi ilmiöt voidaan ymmärtää ilmaisuiksi korkeammasta todellisuudesta, josta niiden merkitys kumpuaa tai merkitys ymmärretään syntyvän ilmiöiden välisistä suhteista, ts. kulttuuri on paradigmaattinen tai syntagmaattinen. (Encyclopedic Dictionary of Semiotics. Berliini, N.Y. \& Amsterdam: Mouton de Gruyter, 1986, s. 166-167.)

Teksti on Lotmanin semiotiikan peruskäsite. Teksti on sanoma, joka on koodattu vähintään kaksi kertaa. Kun jollain luonnollisella kielellä (esim. suomeksi tai venäjäksi) ilmaistu sanoma merkityksellistyy kulttuurikoodin kautta laiksi, näytelmäksi, ivaksi tms., se on teksti. Luonnollisen kielen tasolla tekstin yksittäiset elementit - sanat, lauserakenteet jne. ovat merkityksellisiä yksikköjä. (Kulttuuri)semioottisella tasolla teksti puolestaan on merkityksellinen yksikkö, kielen aineksista muodostunut monimutkainen merkki, jolla on yhtenäinen merkitys.

Ajatus monikertaisesta koodautumisesta ei kuitenkaan ole Lotmanin tekstikäsitteen ydin vaan hän etenee taideteoksen tai paremminkin poetiikan tarkastelun kautta hahmottamaan, mitä tarkoittaa, että teksti on monimutkainen kulttuurista merkitystä kantava merkki. Lotmanin mukaan taiteellinen teksti on "parhaimmillaan" lukuisten kulttuurikoodien määrittämä, ja sille on leimaa antavaa koodien rajojen manipulointi, ts. yhtenäiseksi ja merkitykselliseksi integroitumisen ja ristiriitaisiksi osioiksi hajoamisen vastakkaiset voimat. Potentiaalisesti monikerroksisena ja semiottisesti epäyhtenäisenä tekstinä taideteos on tekstin sosiaalisten funktioiden ruumiillistuma. Teksti on paitsi lähettäjän ja vastaanottajan kommunikaatiota myös lukijoiden ja kulttuuritradition kommunikaatiota (eli teksti kantaa kulttuurin muistia), lukijan kommunikaatiota itsensä kanssa, tekstin ja lukijan välistä kommunikaatiota sekä tekstin ja kulttuurikontekstin välistä kommunikaatiota. Tällä tekstin käsitteellä Lotman pyrkii tavoittamaan kulttuurin aktiivisessa tilassa: teksti on inhimillisen kommunikaation kenttä, kulttuuri kasaantuu tekstiin.

Muodostaessaan tekstin käsitteen poetiikasta ja taiteesta käsin Lotman päätyy siihen, että tekstin ydin on retoriikka eli kielikuvien muodostuminen. Ja koska tekstin käsite on kulttuurin tarkastelun kivijalka, retoriikka on kulttuurintutkimuksen ensisijainen kohde ja näkökulma. Itse asiassa Lotman yleistää kulttuurin käsitteeksi Roman Jakobsonin ajatuksen, että metafora ja metonymia ovat minkä tahansa semioottisen järjestelmän merkityksenmuodostumisen perusta. Kulttuuri eli suhde tekstin, lukijan ja tradition välillä on retoriikkaa, sen sydän on kielikuvan, troopin muodostuminen. Toisaalta retoriikka on kulttuurintutkimuksen näkökulma par excellence: kulttuurien typologisointi on retoriikan tutkimusta, niin semanttisen kuin tyylillisen retoriikan luokittelua.

\section{Retoriikan subjekti}

Lotmanin kulttuurisemiotiikka on monin tavoin samankaltainen kuin 
jälkistrukturalistiseksi kutsuttu semioottinen lähestymistapa. Lotmanin käsitys tekstistä moniaineksisena ja ristiriitaisia kulttuurin ilmaisullisia elementtejä kantavana muistuttaa Jacques Derridan kirjoituksen ja Julia Kristevan intertekstuaalisuuden "käsitteitä". Lisäksi Lotmanin ajatus, että taiteellista tekstiä hallitsevat tekstuaalisen merkityksen integroitumisen ja hajoamisen tendenssit, on samantapainen kuin Roland Barthesin Balzac-luennassa ( $S / Z$, 1970) esittämä luettavan (lisible) ja kirjoittautuvan (scriptible) tekstin ero. Lotmanin ja Barthesin käsitys tekstistä on myös siinä mielessä samanlainen, että kun Lotmanille tekstin ydin on luonnollista kieltä ylemmän tason koodautuminen, Barthesille tekstuaalisuus on konnotaatioiden tason ilmiö. Lotmania ja jälkistrukturalisteja yhdistää myös ajankohta: niin Tartossa kuin Pariisissa 1960- ja 70lukujen vaihteessa näkökulmaa merkitysten muodostumiseen etsittiin kirjallisuudesta ja taitesta.

Lotmanin tekstin käsite tuo semioottiseen teoriaan lukijan. Hänellä ei kuitenkaan ole teoriaa lukevasta tai laajemmin tekstuaalisesta subjektista päinvastoin kuin $\mathrm{mm}$. Kristevalla, jolle Jacques Lacanin psykoanalyysi tarjoaa käsityksen subjektista. Kummassakin tapauksessa lukija-aseman postulointi muuttaa strukturalistisen semiotiikan kommunikaatio- tai paremminkin semioottisten vaikutusten teoriaksi. Lotmanin teoriaa kuitenkin hallitsevat koodin ja merkityksen käsitteet, joiden myötä se ankkuroituu staattisuuteen ja subjektittomuuteen. Vaikka Lotman korostaakin tekstin moniaineksisuutta ja elävyyttä, hänellä ei ole subjektin käsitettä, joka sallii $\mathrm{mm}$. Kristevan puhua koodien ja merkitysjärjestelmien sijasta tekstuaalisista prosesseista ja käsittää teksti dynaamisena.

Kyse on siitä, millä tavoin teoria sallii käsittää sanoman monikerroksisen merkitykset ja uudelleenmerkityksellistymisen potentiaalin. Lotman määrittää tekstin yh- täältä kulttuurikoodin avulla, toisaalta retorisena liikkeenä. Näiden kahden käsityksen väliin jää kuilu: kulttuurikoodi ei selitä tekstin liikettä. Tämän kuilun yli Lotman yrittää rakentaa siltaa selittämällä retoriikkaa taiteellisesta luovuudella ja kummallisilla käsityksillä tekstistä itsenäisenä älynä. Tämä johtuu siitä, ettei Lotmanilla ole käsitteitä, jotka sitoisivat yhteen tekstin retorisen dynamiikan ja subjektin dynamiikan. Hänen hahmottamassaan kommunikaatiotilanteessa teksti ja lukija jäävät itsenäisiksi asemiksi, jotka jakavat saman staattisen kulttuurikoodin. Psykoanalyyttisessa semiotiikassa retorinen prosessi, tekstin tuotanto jäsentyy tiedostamattoman ja halun käsittein. Tekstiä liikuttavat libidoenergioiden ja sosiaalisten/ kulttuuristen järjestysten kohtaaminen, ja teksti tuottaa "sananmukaisuuksiensa" ohella tiedostamattoman, Halun konstellaatioita lukija-asemina.

Lotmanin kulttuurisemiotiikan ja psykoanalyyttisen semiotiikan taitekohtaa valaisee hyvin troopin käsite. Lotmanin mukaan troopin kulttuurinen funktio on ilmaista se, mitä muuten ei voi ilmaista. Kuitenkaan hän ei kerro, mitä nämä ilmaisun esteet ovat ja miten ne toimivat. Psykoanalyyttinen semiotiikka hahmottaa tämän tilanteen torjunnan, siirtymän ja tiivistymän käsittein: trooppeihin on tiivistynyt ja siirtynyt se, mikä on torjuttu.

\section{Elokuvatekstiä}

Elokuvan semiotiikkaa ja elokuvaestetiikan ongelmia on Merkkien maailman pisin, yli satasivuinen essee, eikä ihme, sillä elokuva sallii Lotmanin konkretisoida kulttuurisemiotiikan käsitteitä oivallisesti. Elokuvan semioottista luonnetta pohtiessaan hän pystyy ensiksikin esittämään painokkaasti jaottelunsa ehdollisiin ja kuvaaviin merkkeihin eli sanoihin ja kuviin (C.S. Peircen termein symboleihin ja ikoneihin). Sanan ja kuvaan sekä niiden välisiin suhteisiin pe- rustuu kaikki inhimillinen kommunikaatio, ja tämä jaottelu onkin Lotmanin kielikuvan teorian perusta. Elokuva on sana- ja kuvataiteen yhdistelmä, se perustuu sanaja kuvamerkitysten dialektiikkaan. Toiseksi kuvan polyseemisyyden ja elokuvan moniaineksisuuden vuoksi elokuvaa on mielekästä analysoida semioottisesti ensisijaisesti tekstinä eikä esim. kuvan kieliopista lähtien. Tämän vuoksi elokuva on Lotmanille hyvää esimerkkiaineistoa.

Lotmanin elokuvaessee on tiivis esitys 1960-luvun alkupuolella alkaneen elokuvasemiotiikan I vaiheen ongelmakentästä, jota aitasivat $\mathrm{mm}$. Pier Paolo Pasolinin ajatukset elokuvan kielestä ja fotogrammin käsite sekä Christian Metzin kuvanauhan suuri syntagmatiikka. Elokuvasemiotiikka tarkasteli elokuvaa saussurelaisittain kielenä ja yritti etsiä elokuvan kielioppia.

Ensimmäinen karikko oli elokuvallisen merkin eristäminen. Ongelmallista oli ensinnäkin se, että filmille valottunut elokuvan kuva ei ole arbitraarinen eli puhtaasti konventionaalinen vaan kohteensa motivoima paitsi esittävyytensä myös kuvan muodostumisen teknis-fysikaalisen prosessin kautta. Peircen sanoin elokuvan kuva on ensisijaisesti ikoni ja indeksi ja vasta toissijaisesti symboli. Vakavampi semioottinen ongelma oli kuitenkin se, että elokuvan kuvassa on lukuisia erilaisia merkityksiä kantavia elementtejä, joista näytti olevan mahdotonta eristää elokuvallista merkkiä. Se, että kuvat luovat liikkeen vaikutelman, lisäsi vaikeuksia. Niinpä Metz luopui elokuvallisen merkin määrittelemisestä ja katsoo, että otos elokuvallisen merkityksen yksikkönä on luonteeltaan syntagma tai paremminkin lausuma. Edelleen hän katsoi, että elokuvan kielioppi voidaan määrittää vain retoriikan tasolla, ja kehitti "Grande syntagmatiquen" eräänlaiseksi elokuvan retoristen mahdollisuuuksien kartaksi.

Siitä huolimatta, että Lotman 


\section{ENSIMMÄINEN SUOMALAINEN KOKONAISESITYS VIERAASTA KULTTUURISTA JA SIVILISAATIOSTA}

puhuu kuvarajauksen muodostavan elokuvallisen merkin, hänen elokuvasemiotiikkansa on perusteiltaan hyvin samanlaista kuin Metzin. Hän tarkastelee elokuvaa tekstinä, ts. kuvien toisen tason koodautumista eli retorista merkitystä. Metzin tapaan hän korostaa elokuvaretoriikan syntagmaattista luonnetta: hänelle elokuvallinen merkitys muodostuu ensisijaisesti kertomuksen ja montaasin - jolla hän tarkoittaa sekä kuvarajausta että kuvanauhan organisointia eli leikkausta - kautta. Elokuva tekstinä välittää ja luo merkityksiä, jotka ylittävät filmille valottuneiden kuvien luoman todellisuusilluusion. Montaasi eli kuvien rakentaminen ja toisiinsa liittäminen on tärkein tapa, jolla elokuva muuttuu todellisuuden mekaanisesta tallentamisesta taiteeksi. Ei ole ihme, että Lotmanille elokuvaestetiikan sankari on Sergei Eisenstein.

Ilpo Helén
HUOTARI, TAUNO-OLAVI \& SEPPÄLÄ, PERTTI: Kiinan kulttuuri. Otava 1990.

\section{Ensimmäinen suomalainen kokonaisesitys}

Sanottakoon tärkein heti alussa: Renvall-instituutin tutkija TaunoOlavi Huotari ja Kiinan kulttuurin tuntiopettaja ja kirjakauppias Pertti Seppälä ovat tehneet pioneerityön ja teoksen kustantaja kulttuuriteon. 500-sivuista kirjaa on siksi mahdoton suomeksi arvostella kaikkea muuta myöhemmin kielellämme Kiinasta kirjoitettavaa tullaan vertaamaan tähän perusteokseen. Kysymys on ymmärtääkseni myös ensimmäisestä kokonaisesityksestä. Esimerkiksi Ilmari Vesterisen teos Japanilaiset (1987) ei ole varsinkaan historialliselta osaltaan yhtä kattava kuin Kiinan kulttuuri.

Kirja on lisäksi selvästi käyttökelpoisempi kuin esimerkiksi ensimmäiseksi mieleentuleva vastaavankaltainen englanninkielinen teos (Blunden \& Elvin 1983). Mainiointa on, ettei suomalaisessa yhteiskuntateoreettisessa keskustelussa ei — kai? — enää tämän teoksen ilmestymisen jälkeen voida vedota täydelliseen tietämättömyyteen Kiinan historiasta ja olosuhteista.

Teoksessa on runsas ja oivaltava kuvitus. Sen tekevät mahdolliseksi laajat marginaalit, joita käytän nyt hyväkseni esittämällä joitakin reunahuomautuksia.

Kiinan historian esittäminen aloitetaan kirjassa tyylikkääseen ranskalaiseen annalistitapaan hitaasti muuttuvasta (ennen kaikkea geografiasta) ja suurista linjoista (amerikkalainen sanoisi niitä kai megatrendeiksi), kuten sivilisaation leviämisestä kohti etelää, byrokratian kasvusta, rajakansojen aikaansaamasta dynamiikasta.

Varsinaisessa Kiinan historian esittämisessä on törmätty tilaongelmaan: koko suuri kertomus esitetään 55 sivulla, joista 25 käytetään tähän vuosisataan. Voi, jospa tekijöiden olisi ollut mahdollista julkaista teos kahdessa osassa (historia\&yhteiskunta/kulttuuri)! Mutta ei auta itku kirjamarkkinoillakaan. Sitäpaitsi pikanteista yksittäiskertomuksista kiinnostuneet voivat etsiä käsiinsä aikaisemmin ilmestyneen Huotarin teoksen $\mathrm{Kii}$ nan nähtävyyksiä (1988), jonka sisältöä vastaava nimi oikeastaan tulisi olla "Kiinan historiaa kulttuurimonumenttien kautta kerrottuna".

Propedeuttisista syistä esitys on jaettu toisaalta vanhaan, perinteiseen Kiinaan, toisaalta nykyiseen (yhteiskunta), tämän vuosisadan Kiinaan (historia). Näistä aiheista kirjassa vastaa Huotari. Vanhan Kiinan tarkastelussa nousee esiin muutamia Kiinalle ominaisia erityispiirteitä. Ensiksikin isän suvun perinteisen laaja merkittävyys Kiinassa (s. 105, jatkossa teoksen sivunumerot suluissa) ja siihen elimellisesti liittyvä perheen, suvun ja yhteiskunnan eriytymättömyys toisistaan; toiseksi Kiinaa muista säätyvaltaisista sivilisaatiosta erottava meritokraattinen virkamiesvaltaisuus (168); kolmanneksi kaupunkien itsehallinnon puuttuminen (118). "Varsinais-Kiinasta" puhuttaessa ei liene vailla merkitystä se tekijöiden toteamus, että Kiinan historiassa jatkuvasti "Eurooppaa pienempi alue on elättänyt sitä selvästi suuremman väestön" (21).

Kieltä, kalligrafiaa, kirjallisuutta ja taiteita ja tapakulttuuria koskevista osista on vastannut Pertti Seppälä. Luvuissa esitetään lukemattomia kiinalaisia kulttuuriartefaktojen luokitteluja, jotka näyttävät olevan Seppälän "lemmikkejä", hänen usein toistuvaa mielitermiään käyttääkseni. Populaarisinta osaa teoksessa edustanevat johdatukset kiinalaisiin teenjuontitapoihin ja horoskooppiin.

Mainiota on, että teoksessa on myös siirrytty käyttämään puhtaasti pinyin-translitteraatiota, josta ennemmin tai myöhemmin tulee yksin hallitseva kirjoitustapa. Kirjan lopun translitteraatioiden muutostaulukko (Wade-Giles/pinyin) on korvaamaton. Lisäksi pinyinin 